https://doi.org/10.15407/ujpe63.6.513

N. KUTSEVOL, A. NAUMENKO, V. CHUMACHENKO, O. YESHCHENKO, YU. HARAHUTS, V. PAVLENKO

Taras Shevchenko National University of Kyiv (64/13, Volodymyrs'ka Str., Kyiv 01601, Ukraine)

\title{
AGGREGATION PROCESSES IN HYBRID NANOSYSTEM POLYMER/NANOSILVER/CISPLATIN
}

\begin{abstract}
Hybrid nanosystems consisting of star-like copolymer Dextran-graft-Polyacrylamide in the anionic form (D-g-PAA(PE)), silver nanoparticles (AgNPs), and cisplatin (cis-Pt) have been synthesized in water and characterized by TEM, DLS, FTIR, and UV-Vis spectroscopies. It is shown that cis-Pt forms a complex with carboxylate groups of the polymer. For the ternary system Polymer/AgNPs/cis-Pt, a change in the hydrophilic-hydrophobic balance of a polymer molecule (due to the complexation with cis-Pt) and the aggregation of macromolecules, as well as to some agglomeration AgNPs, are revealed. The decrease of the antitumor efficiency of the hybrid ternary nanosystem Polymer/AgNPs/cis-Pt in comparison with the Polymer/cis-Pt system is discussed.
\end{abstract}

Ke ywords: silver nanoparticles, branched polymer, polyelectrolyte, cisplatin, aggregation.

\section{Introduction}

Cancer remains a major healthcare problem in the world despite strong research efforts toward tackling the disease [1-2]. The nanomedicine seems to be the promising approach in designing the cancer therapies, mainly because nanosystems for the drug delivery have likelihood to increase the circulation halflife of the $\operatorname{drug}(\mathrm{s})$, improve pharmacokinetics, and reduce side effects [3]. Such nanosystems-nanocarriers are typically less than $200 \mathrm{~nm}$ in diameter [4]. Nanoparticles assist in the delivery of drugs. The enhanced permeability and retention effect (EPR effect) are observed in the cancer environment [5].

Cisplatin (Cis- $\left[\mathrm{Pt}(\mathrm{II})\left(\mathrm{NH}_{3}\right)_{2} \mathrm{Cl}_{2}\right]$ ) (cis-Pt) is one of the most extensively used chemotherapeutic drugs for the cancer treatment [6-9]. It is efficient against various types of cancers, including carcinomas, germ cell tumors, lymphomas, and sarcomas [10]. A special attention is paid to its molecular mechanisms of action and to its undesirable side effects [10]. It is known that cis-Pt has ability to cross-link DNA, thereby preventing the strands from the uncoiling and separation. This process prohibits the division of cells and leads to cellular apoptosis $[6-8,10,11]$. It was shown

(C) N. KUTSEVOL, A. NAUMENKO,

V. CHUMACHENKO, O. YESHCHENKO,

YU. HARAHUTS, V. PAVLENKO, 2018

ISSN 2071-0194. Ukr. J. Phys. 2018. Vol. 63, No. 6
$[11,12]$ that $90 \%$ of cis-Pt are bound to plasma proteins in blood and, thus, do not enter the cells. That leads to a less therapeutic efficacy. To prevent this process and to increase the antitumor effect of the drug, the incorporation of cis-Pt molecules to nanosized carriers like polymers is used [13-16]. Such conjugates improved the drug pharmacokinetics and results in an increased drug accumulation in tumors, which is based on the "enhanced permeability and retention" effect.

Polymer nanocarriers can improve the drug solubility, prolong the systemic drug half-life, and reduce harmful side effects. Moreover, such system can deliver simultaneously two or more drugs for the combination therapy $[16,17]$. It was reported that linear water-soluble polymers, block copolymers able to form micelles [13-17], and branched polymers have been studied as nanocarriers for chemotherapeutic agents [18]. Such nanosystems containing cis-Pt can be efficiently accumulated in the tumors, thereby enhancing the antitumor action.

It was reported [19] that the chloride ligands in cisPt could be substituted by a variety of ligand groups. Particularly, when the chloride ligands in cisplatin are substituted with carboxylates, the resultant complexes demonstrated a good antitumor activity and decreased toxic side effects. Thus, cisplatin delivery systems based on carboxylate-containing polymers 
represent a promising approach to create high-efficient anticancer nanosystems [20, 21]. Polymer drug complex PEO-poly(aspartic acid)/cis-Pt, PEOpoly(glutamic acid) block copolymers/cis-Pt [19], triblock copolymer micelles PEG-b-PCL-b-PAA/cis-Pt [20], a core-shell-type star polymer consisting of hyperbranched polystyrene (hydrophobic core) and arms of poly(acrylic acid) (hydrophilic shell)/cis-Pt [21] formed in a water medium were studied.

The theoretical $[22,23]$ and experimental [24-29] studies of branched polymers provide us with a reason to assume that these macromolecules are more efficient in comparison with linear analogs for the nanosystem in situ synthesis, as flocculants and nanocarriers for drugs, because of a higher local concentration of functional groups capable of reacting with some substances. It was proved by our recent research devoted to the encapsulation of cis-Pt into a branched star-like polymer with dextran core and grafted polyacrylamide-co-polyacrylic acid arms. It was shown [29] that copolymers were absorbed by macrophages (murine macrophage cell line) and were not cytotoxic. The phagocytic index was equal to $84 \%$. The complexes Polymer/cisplatin were evaluated for the cell viability for K-562 (human chronic myelogenous leukemia) and U-937 (human histiocytic lymphoma) cell lines in the range of loaded cisplatin concentrations from 0.1 to $10 \mathrm{~g} / \mathrm{ml}$. Nanosystems caused a decrease in the cell viability to about $22 \%$ and $39 \%$ for U-937 and K-562 cell lines, respectively. To enhance the antitumor efficiency of a nanocarrier, it was decided to add silver nanoparticles into the prepared nanosystem. It is well known that nanosilver $(\mathrm{AgNPs})$ has been widely applied in biomedicine [30] and clinical practice [31-33].

Recently, nanosilver has been reported for its anticancer effect [31-33], probably accounting for the intracellular induction of reactive oxygen species, JNK pathway activation, and DNA damage, but its mechanisms still largely remain unclear.

However, metallic nanoparticles have a tendency to aggregate due to their large surface energy and can lose their biological activity. It was reported [25] that Ag sol synthesized in situ in a polymer solution Dextran-graft-(Polyacrylamide-co-Polyacrylic acid) was stable in time. The binary Polymer/AgNPs and ternary Polymer/AgNPs/cis-Pt nanosystems were tested for cytotoxic effects [29]. The synergetic effect toward malignant cell was expected for the Polymer/AgNPs/cis-Pt system. The results revealed a dose-dependent decrease in the viability for U-937 and K-562 cell lines exposed to silver. However, when the copolymers were conjugated to both nanosilver and cisplatin, such a nanosystem displayed a less cytotoxic effect compared to the conjugates of polymer and cis-Pt [29].

The goal of the present study is to study the hybrid nanosystem dextran-graft-(polyacrylamide-copolyacrylic acid)/AgNPs/cis-Pt with the aim to understand the reason for a decrease of its untitumor efficiency (negative synergetic effect) in comparison with the Polymer/cis-Pt system.

\section{Materials and Methods}

\subsection{Polymer nanocarrier}

As a nanocarrier, we used a branched copolymer obtained by grafting polyacrylamide (PAA) chains onto dextran $\left(M_{w}=7 \times 10^{4} \mathrm{~g} / \mathrm{mol}^{-1}\right)$ backbone [25], by using the ceric-ion-reduce initiation method. This redox process initiates free radical sites exclusively on the polysaccharide backbone, thus preventing from the formation of a polyacrylamide homopolymer.

The details of the synthesis, identification, and analysis of the internal polymer structure were described in [25, 27]. The theoretical number of grafting sites per polysaccharide backbone for the sample we used as a polymer nanocarrier in the present work was equal to 5 , and the related dextran-graftpolyacrylamide copolymer was referred as D70-gPAA. The choice of this copolymer among the series of the branched samples synthesized is based on our previous research. Namely, this sample was the most efficient polymer matrix for the $\mathrm{Ag}$ sol in situ synthesis $[24,25,29]$.

The D70-g-PAA copolymer was saponified by alkaline hydrolysis, by using $\mathrm{NaOH}$ to obtain branched polyelectrolyte Dextran-graft-(Polyacrylamide-coPolyacrylic acid) referred as D70-g-PAA(PE) throughout [27]. The degree of saponification of carbamide groups to carboxylate ones onto PAA-grafted chains determined by the potentiometric titration was equal to $43 \%$ [27].

\subsection{Binary nanosystem polymer/AgNPs preparation}

AgNPs were synthesized by the reduction of an $\mathrm{Ag}$ precursor $\left(\mathrm{AgNO}_{3}\right)$ dissolved in a polymer solu-

ISSN 2071-0194. Ukr. J. Phys. 2018. Vol. 63, No. 6 
tion. $2 \mathrm{ml}$ of a $0.1 \mathrm{M} \mathrm{AgNO}_{3}$ aqueous solution was added to $5 \mathrm{ml}$ of the aqueous polymer solution $(C=$ $\left.=1 \times 10^{-3} \mathrm{~g} \cdot \mathrm{cm}^{-3}\right)$ and stirred during $20 \mathrm{~min}$. Then $2 \mathrm{ml}$ of a $0.1-\mathrm{M}$ aqueous solution of $\mathrm{NaBH}_{4}$ was added. The final aqueous solution was stirred during $30 \mathrm{~min}$. It turned reddish brown, thus the formation of AgNPs was indicated.

\subsection{Ternary nanosystem polymer/AgNPs/cis-Pt preparation}

$1 \mathrm{ml}$ of cis-Pt $(C=0.5 \mathrm{mg} / \mathrm{mL})$ was added dropwise to the $1 \mathrm{~mL}$ of the initial solution of $\mathrm{D}$-gPAA $/ \operatorname{AgNPs}\left(C_{\text {polymer }}=1 \mathrm{mg} / \mathrm{mL}\right)$ under the stirring for $30 \mathrm{~min}$. In all experiments, we used the cis-Pt concentrate ("cisplatin-TEVA", Pharmachemie B.V., Netherlands) at an initial concentration of $0.5 \mathrm{mg} / \mathrm{ml}$.

\subsection{Size-exclusion chromatography}

SEC analysis was carried out, by using a multidetection device consisting of a LC-10 AD Shimadzu pump (throughput $0.5 \mathrm{ml} / \mathrm{min}$; Japan), an automatic injector WISP $717+$ from Waters (USA), three coupled 30-cm Shodex OH-pak columns (803HQ, 804HQ, and 806HQ; Munich, Germany), a multiangle light scattering detector DAWN F from Wyatt Technology (Germany), and a differential refractometer R410 from Waters. Distilled water containing 0.1 M $\mathrm{NaNO}_{3}$ was used as an eluent. Dilute polymer solutions $\left(c=3 g L^{-1}<c^{*}=1 /[\eta]\right)$ were prepared, allowing for neglecting the intermolecular correlations in the analysis of light scattering measurements.

\subsection{Fourier transform infrared (FTIR) spectroscopy}

FTIR spectra were obtained on a Nicolet NEXUS475 (USA) spectrophotometer in the range 4000$400 \mathrm{~cm}^{-1}$, by using thin films $(l=6-9 \mu \mathrm{m})$. The films were cast from aqueous solutions of the polymer without adding of cisplatin and with cisplatin.

\subsection{Transmission electron microscopy (TEM)}

For the sample preparation, 400 mesh $\mathrm{Cu}$ grids with plain carbon film were rendered hydrophilic by a glow discharge treatment (Elmo, Cordouan Technologies Bordeaux France). A $5 \mu \mathrm{l}$ drop was deposited and let adsorbed for $1 \mathrm{~min}$; then the excess of solution was removed with a filter paper piece. The observations of the AgNPs were carried on two TEMs, Tecnai G2 or
CM12 (FEI, Eindhoven Netherlands), and the images were acquired with a ssCCD Eagle camera on the Tecnai and a Megaview SIS Camera on CM12.

\section{7. $U V$-vis spectroscopy}

UV-visible absorption spectra were recorded by a Cary 60 UV-VIS spectrophotometer (Agilent Technologies, Inc.) in standard quartz cuvettes $1 \mathrm{~cm}$ in thickness at room temperature (range 200-1000 nm).

\subsection{Quasielastic light scattering (QELS)}

QELS measurements were carried out, by using a Zetasizer Nano ZS90 (Malvern Instruments Ltd., UK). The apparatus contains a $4-\mathrm{mW} \mathrm{He}-\mathrm{Ne}$ laser with a wavelength of $632.8 \mathrm{~nm}$, and the scattered light is detected at an angle of $173^{\circ}$ (back scattering). For the accurate hydrodynamic diameter distribution characterization, at least 20 correlograms were collected for each sample. Correlograms were treated by the CONTIN algorithm that is known to be reliable for complicate systems [34] to get appropriate hydrodynamic diameter distributions.

\section{Results and Discussions}

The star-like water-soluble copolymer dextran-graftpolyacrylamide in the anionic form was used for the fabrication of binary Polymer/AgNPs and ternary Polymer/AgNPs/cis-Pt nanosystems. The molecular parameters of D70-g-PAA copolymer before the alkaline hydrolysis determined by size-exclusion chromatography (SEC) are: $M_{w}=2.15 \times 10^{6} \mathrm{~g} / \mathrm{mol}$, $R_{g}=85 \mathrm{~nm}$, and $M_{w} / M_{n}=1.72$. The peculiarities of the molecular structure of this copolymer, as well as its anionic derivative, were discussed in $[25,27]$. D70-g-PAA(PE) copolymer was consisted of biocompatible components, dextran (core) and polyacrylamide (grafts), and was nontoxic and watersoluble [29]. Macromolecules of D70-g-PAA(PE) were tested as nanocontainers-carriers for the targeted delivery of drugs to tumor cells and revealed a high efficiency [29]. To enhance the antitumor efficiency of the nanocarrier, the ternary nanosystem Polymer/AgNPs/cis-Pt was examined in vitro on malignant cells, but the cytotoxic effect was less than for the binary nanosytem Polymer/cis-Pt.

To understand the reason for decreasing the antitumor efficiency (negative synergetic effect) of the ternary system containing AgNPs and cis-Pt incorporated into the polymer matrix in comparison with 


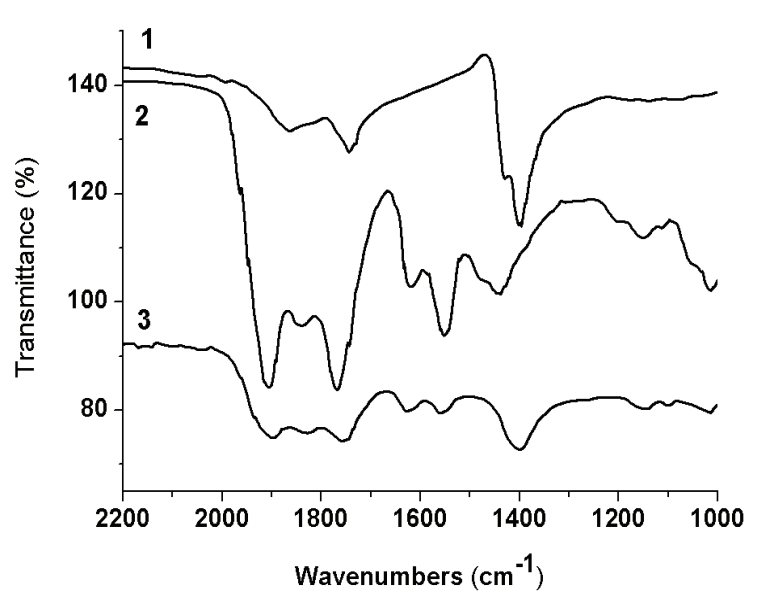

Fig. 1. FTIR spectra (amide1-amide2 region) for the systems: cis-Pt (1), D70-g-PAA(PE) (2), and D70-g-PAA(PE)/cisPt (3)

the binary system Polymer/cis-Pt, the comparative study of these nanosystems was performed by FTIR, TEM, QELS, and UV-vis methods.

The complex formation in the D70-g-PAA(PE)/cisPt system was proved by FTIR. Spectra of Polymer/cis-Pt in comparison with the individual polymer and cis-Pt were analyzed in the amide1 and amide2 region (Fig. 1). For D70-g-PAA(PE), the characteristic peaks are observed in the region of amide 1 (1650-1660 $\mathrm{cm}^{-1}$, CO stretching vibrations) and amide $2\left(1615 \mathrm{~cm}^{-1}\right.$, NH bending vibrations (40$60 \%)$; $\mathrm{C}-\mathrm{N}$ stretching vibrations $(18-40 \%))$. An additional peak at $1570 \mathrm{~cm}^{-1}$ (COO-, stretching vibrations) appears [35]. The complex formation of cis$\mathrm{Pt}$ with the copolymer carboxyl groups is evident (Fig. 1, curve 3).

The TEM image of silver sols (binary system Polymer/cis-Pt) synthesized in branched anionic polymer matrices is represented in Fig. 2. This binary system was described in [25] in detail. It was reported that, along with AgNPs with a size of 10-15 nm, NPs with a size of $2-5 \mathrm{~nm}$ are also formed (Fig. 2).

The interaction of silver ions with the anionic polymer matrix takes place with both carbamide (as in nonionic polymers) and carboxylate groups. Moreover, the interaction has the following different mechanisms: the ion-dipole interaction in the first case and the electrostatic one in the second one. It is supposed that, on the carbamide groups of ionic matrices, the same particles are formed as in nonionic matri-

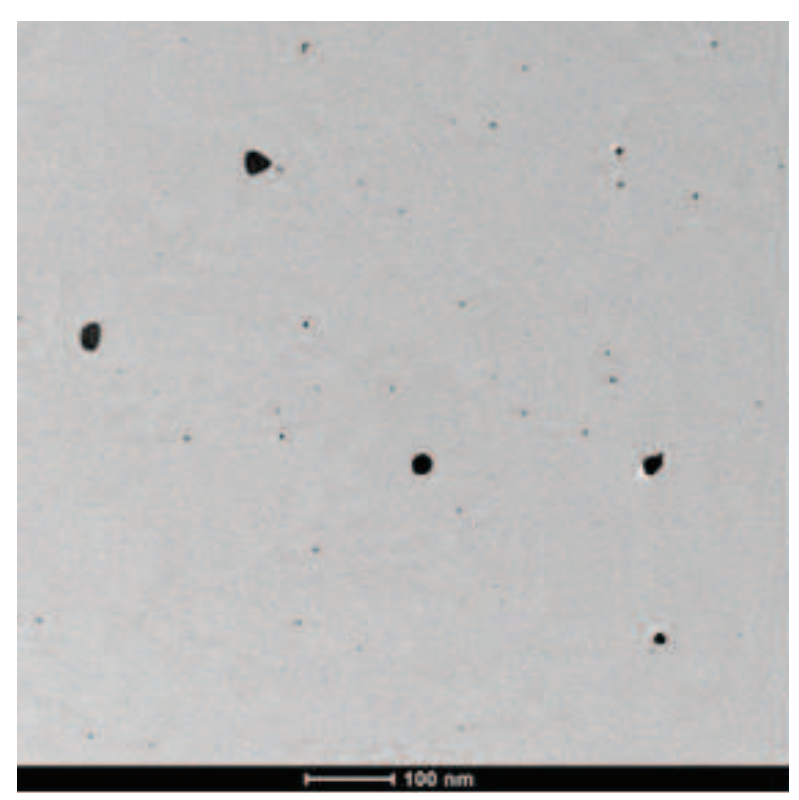

$a$

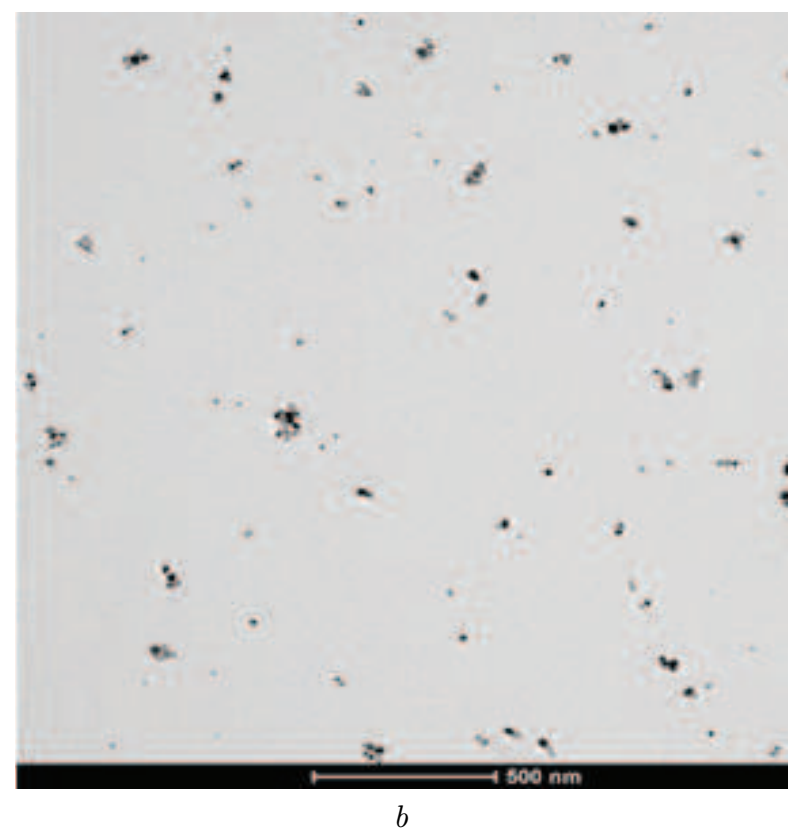

Fig. 2. TEM images of the nanosystem Polymer/AgNPs. Just after the synthesis $(a)$, in one month after the synthesis $(b)$

ces. However, the particles on the carboxylate groups are smaller (Fig. 2).

The TEM images of the ternary nanosystem Polymer $/ \mathrm{AgNPs} /$ cis-Pt are shown in Fig. 3. It is evident that individual AgNPs are the same in size as in the binary system Polymer/AgNPs $(a)$, but some aggre-

ISSN 2071-0194. Ukr. J. Phys. 2018. Vol. 63, No. 6 


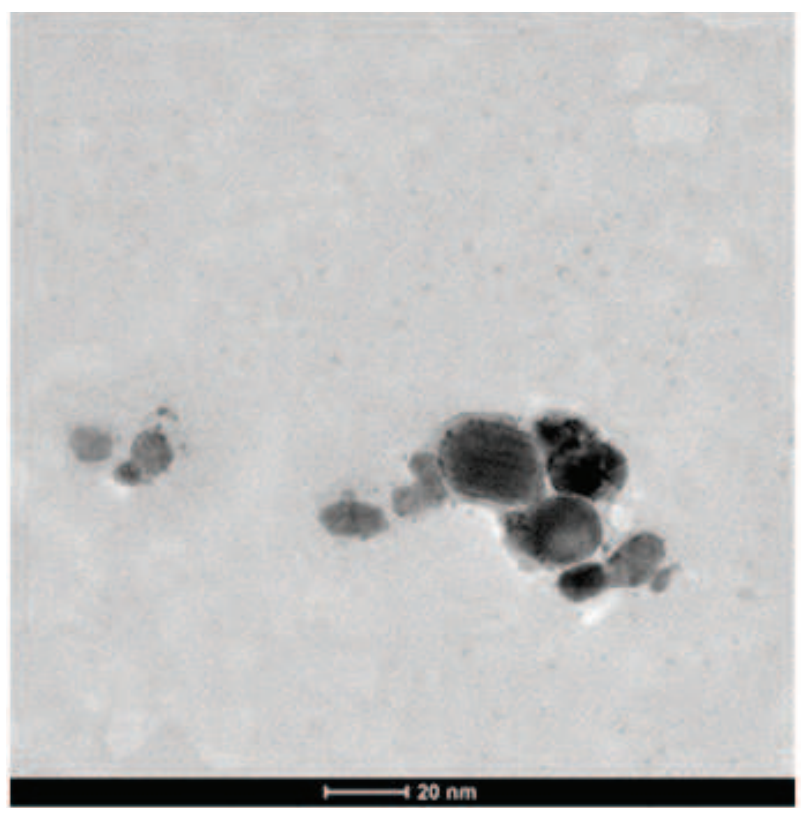

$a$

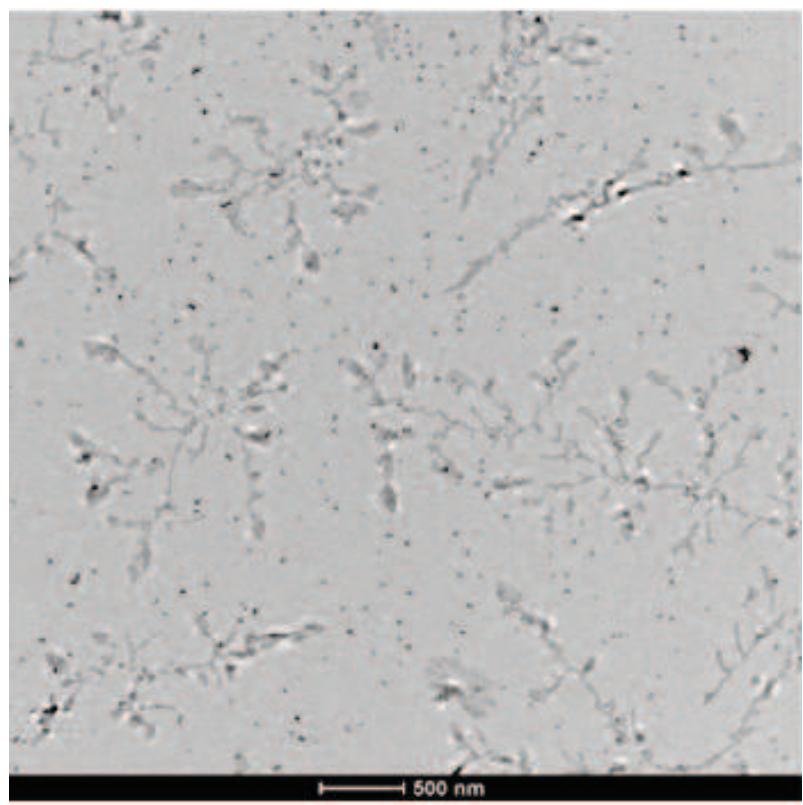

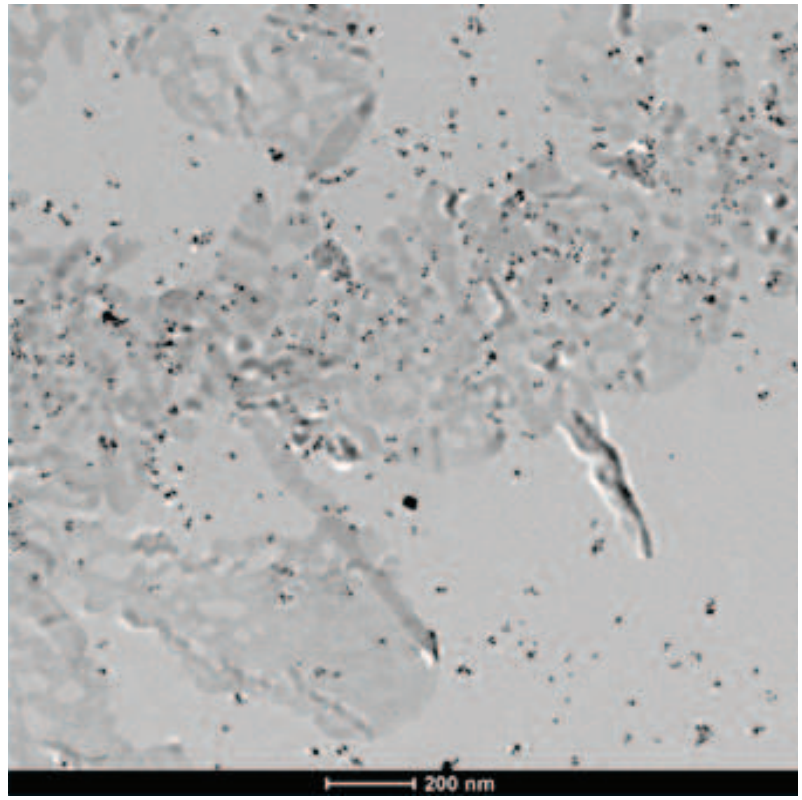

$b$

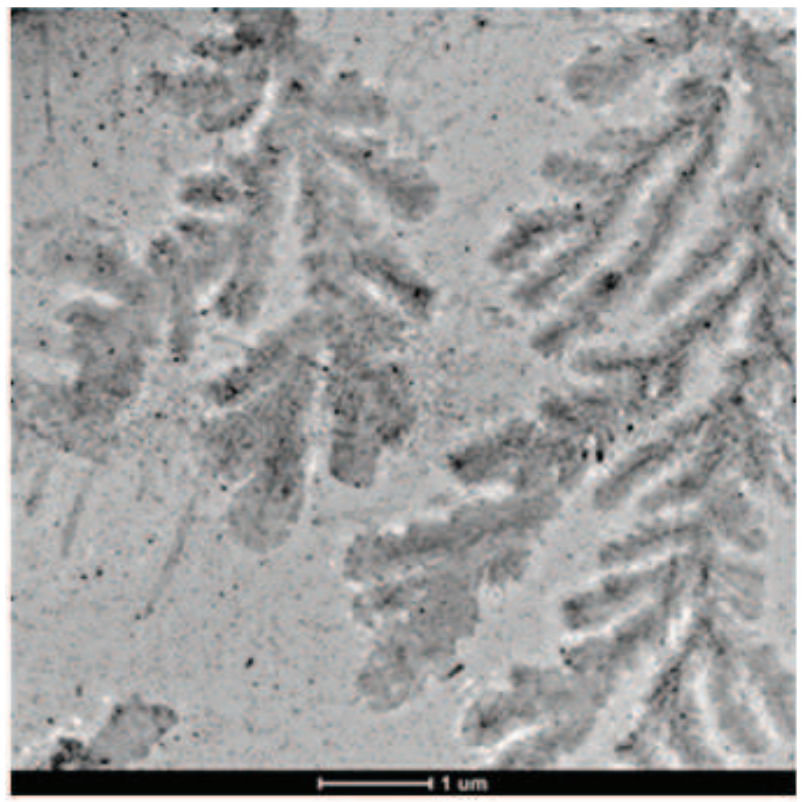

$d$

Fig. 3. TEM images of the ternary nanosystem Polymer/AgNPs /cis-Pt: just after the synthesis (a); in one week after the synthesis $(b, c)$, in one month after the synthesis $(d)$

gation process is evident $(a)$, and the "visualization" of polymer molecules observed $(b, c)$. For the mixture Polymer/AgNPs/cis-Pt, specific continuous superstructures resembling dendrites in shape are seen. This looks as "leafs of fern" (Fig. 3, c). Obviously,
cis-Pt forms a complex with functional groups of the polymer matrix, and the hydrophilicity of the macromolecule decreases. This causes the appearance of hydrophobic domains, which forms a structure in the water medium. In addition, the enlarging in size of 

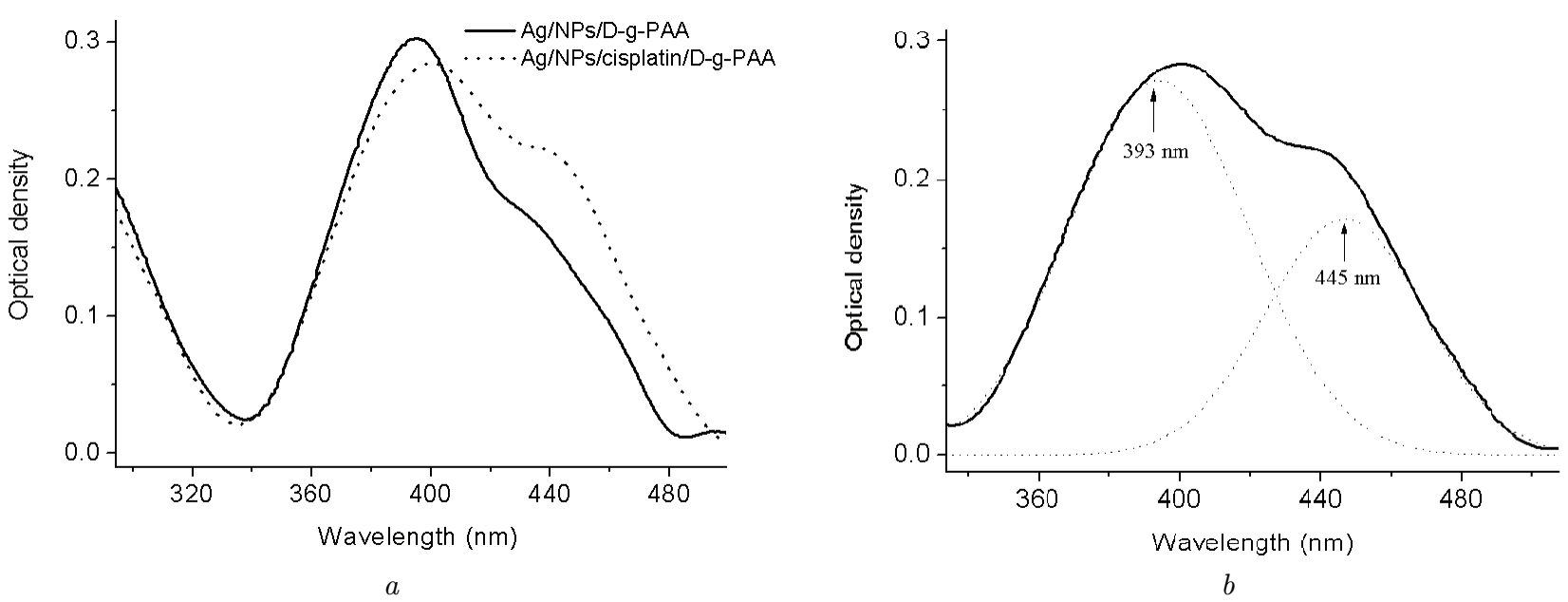

Fig. 4. Absorption spectra of Polymer/AgNPs and Polymer/AgNPs/cis-Pt nanosystems in water (a), peak fitted absorption spectrum of Polymer/AgNPs/cis-Pt (b)

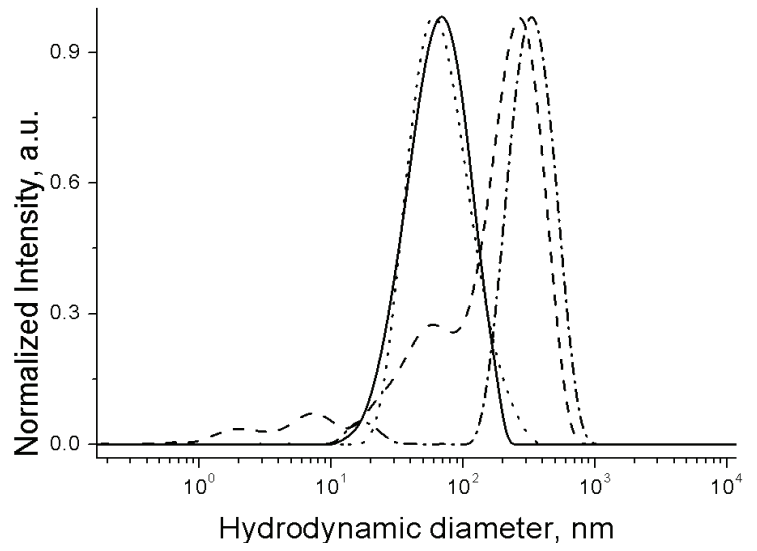

Fig. 5. Hydrodynamic diameter distribution of Polymer solid line, Polymer/cis-Pt - dotted line, Polymer/AgNPs dashed line, Polymer/AgNPs/cis-Pt - dash-dotted line

the polymer nanocarrier caused by the aggregation of macromolecules in time was revealed.

The aggregation states of AgNPs have an effect on their optical properties. UV-visible spectroscopy can be used as a simple characterization technique for monitoring the nanoparticle solutions. The corresponding absorption spectra are shown in Fig. 4.

It is known that the cis-Pt absorption spectrum in water has the absorption bands in the interval 200250 and at $305 \mathrm{~nm} \mathrm{[36].} \mathrm{For} \mathrm{the} \mathrm{silver} \mathrm{nanoparticles,}$ the interval from $350 \mathrm{~nm}$ to $450 \mathrm{~nm}$ is typical [37], i.e. the absorption spectra of cis-Pt and AgNPs do not overlap. That is why, we will analyze the experimental results only in the region $300-500 \mathrm{~nm}$. From
Fig. 4, one can see that the spectrum of Ag NPs in the polymer without cis-Pt demonstrates the clear surface plasmon resonance (SPR) band with a two-peak structure with maxima at $393 \mathrm{~nm}$ and $445 \mathrm{~nm}$ (solid line in Fig. 4). For the system Polymer/AgNPs/cis-Pt (dotted line), the plasmon band has a two-component structure as well: the peaks have maxima at the same wavelengths of $393 \mathrm{~nm}$ and $445 \mathrm{~nm}$. It is known that the optical properties of silver nanoparticles are changed, when particles aggregate. These leads to the formation of the secondary peak at longer wavelengths due to the aggregates of silver [38-41]. Thus, the short wavelength peak at $393 \mathrm{~nm}(382 \mathrm{~nm})$ can be attributed to SPR in separate $\mathrm{Ag}$ NPs, while the red-shifted one at $445 \mathrm{~nm}(435 \mathrm{~nm})$ can be attributed to the aggregates of Ag NPs. We note that the adding of cisplatin leads to a considerable increase of the intensity of the long-wavelength peak of aggregated NPs comparing to the spectrum of the system without cisplatin. Thus, one can conclude that cis$\mathrm{Pt}$ molecules may induce the aggregation process in the ternary hybrid system. Moreover, the aggregation process is twofold: i) aggregation of $\mathrm{Ag}$ nanoparticles; ii) aggregation of polymer molecules caused by a change of the hydrophylic-hydrophobic balance of macromolecules D-g-PAA(PE). These assumptions are consistent with the DLS data represented below.

The analysis of QELS results revealed that the average hydrodynamic diameter of a D-g$\mathrm{PAA}(\mathrm{PE})$ molecule is almost equal to that of the $\mathrm{D}$-g-PAA(PE)/cis-Pt complex (about $65 \mathrm{~nm}$ ). The 
hydrodynamic diameter distribution of the D-g$\mathrm{PAA}(\mathrm{PE}) / \mathrm{AgNPs}$ system includes several modes (dashed curve on the Fig. 5) - two fractions of single AgNPs (2 and $7 \mathrm{~nm}), \mathrm{D}$-g-PAA(PE) macromolecules $(65 \mathrm{~nm})$, and aggregates $(260 \mathrm{~nm})$. The addition of cis-Pt to D-g-PAA(PE)/AgNPs causes a simplification of the hydrodynamic diameter distribution. The mode of macromolecules disappears (Fig. 5, dasheddotted line), but rising the average size of aggregates from 260 to $340 \mathrm{~nm}$ is observed.

\section{Conclusions}

The complex study of the hybrid ternary nanosystem D-g-PAA(PE)/AgNPs/cis-Pt in a water solution has been performed. It is shown that the formation of the cis-Pt complex with carboxylate groups of the polymer matrix results in changing the hydrophilic-hydrophobic balance of macromolecules. TEM revealed the aggregation process and the "visualization" of polymer molecules for the nanosystem Polymer/AgNPs/cis-Pt. Superstructures that look as leafs of fern and resemble dendrites in shape are observed. An increase of the intensity of the SPR peak of aggregates of AgNPs has been observed for the ternary nanosystem and is explained by the aggregation of AgNPs caused by cis-Pt molecules. The analysis of QELS results has revealed that the addition of cis-Pt to the D-g-PAA(PE)/AgNPs system causes the disappearance of individual macromolecules in the nanosystem and leads to the appearance of aggregates 260 to $340 \mathrm{~nm}$ in size. Thus, a decrease of the antitumor efficiency (negative synergetic effect) of the hybrid nanosystem dextran-graft-(polyacrylamide-co-polyacrylic acid)/AgNPs/cisplatin in comparison with the polymer/cisplatin system [29] can be explained by two facts: (i) the formation of AgNPs aggregates and (ii) the enlarging in size of the polymer nanocarrier caused by the aggregation of macromolecules.

The authors are thankful to M. Rawizo and Cr. Blank from the Institute Charles Sadron (France) for the TEM experiment.

1. R. Jadia, C. Scandore, P. Rai. Nanoparticles for effective combination therapy of cancer. Intern. J. Nanotech. Nanomed. 1, 1 (2016).

2. X. Xu, W. Ho, X. Zhang, N. Bertrand, O. Farokhzad. Cancer nanomedicine: From targeted delivery to combination therapy. Trends Mol. Med. 21, 223 (2015).
3. C.M. Hu, S. Aryal, L. Zhang. Nanoparticle-assisted combination therapies for effective cancer treatment. Ther. Deliv. 1, 323 (2000).

4. E. Gianasi, M. Wasil, E.G. Evagorou, A. Keddle, G. Wilson, R. Duncan. HPMA copolymer platinates as novel antitumour agents: In vitro properties, pharmacokinetics and antitumour activity in vivo. Eur. J. Cancer 35, 994 (1999).

5. U. Prabhakar, H. Maeda, R.K. Jain, E.M. Sevick-Muraca, W. Zamboni et al. Challenges and key considerations of the enhanced permeability and retention effect for nanomedicine drug delivery in oncology. Cancer Res. 73, 2412 (2013).

6. A.-M. Florea, D. Busselberg. Cisplatin as an antitumor drug: Cellular mechanisms of activity, drug resistance and induced side effects. Cancer 3, 1351 (2011).

7. X.P. Dong, T.H. Xiao, H. Dong, N. Jiang, X.G. Zhao. Endostar combined with cisplatin inhibits tumor growth and lymphatic metastasis of Lewis lung carcinoma xenografts in mice. Asian Pac. J. Cancer Prev. 14, 3079 (2013).

8. H. Gheybia, H. Niknejadb, A.A. Entezamia. Polymermetal complex nanoparticles-containing cisplatin and amphiphilic block copolymer for anticancer drug delivery. Designed Monomers and Polymers 17, 334 (2014).

9. T. Boulikas, M. Vougiouka. Recent clinical trials using cisplatin, carboplatin and their combination chemotherapy drugs. Oncol. Rep. 11, 559 (2004).

10. D. Shaloam, P.B. Tchounwou. Cisplatin in cancer therapy: molecular mechanisms of action. Eur. J. Pharmacol. 364 (2014).

11. S.J. Lippard. Cellular processing of platinum anticancer drugs. Nat. Rev. Drug Discovery 4, 307 (2005).

12. M. Galanski, V.B. Arion, M.A. Jakupec, B.K. Keppler. Recent developments in the field of tumor-inhibiting metal complexes. Curr. Pharm. Des. 9, 2078 (2003).

13. G. Mattheolabakis, E. Taoufik, S. Haralambous, M.L. Roberts, K. Avgoustakis. In vivo investigation of tolerance and antitumor activity of cisplatin-loaded PLGA-mPEG nanoparticles. Eur. J. Pharm. Biopharm. 71, 190 (2009).

14. S. Aryal, C.M.J. Hu, L. Zhang. Polymer-cisplatin conjugate nanoparticles for acid-responsive drug delivery. ACS Nano 4, 251 (2010).

15. K. Osada, R.J. Christie, K. Kataoka. Polymeric micelles from polyethylene glycol-polyamino acid block copolymer for drug and gene delivery. J. R. Soc. Interface 6, S325 (2009).

16. S.S. Kulthe, Y.M. Choudhari, N.N. Inamdar, V. Mourya. Polymeric micelles: Authoritative aspects for drug delivery. Des. Monomers Polym. 15, 465 (2012).

17. M. Baba, Y. Matsumoto, A. Kashio, H. Cabral, N. Nishiyama, K. Kataoka, T. Yamasoba. Micellization of cisplatin NC-6004 reduces its ototoxicity in guinea pigs. J. Controlled Release 157, 112 (2012).

18. K.J. Haxton, H.M. Burt. Hyperbranched polymers for controlled release of cisplatin. Dalton Trans. 5872 (2008). 
19. C. Wang, Y. Gong, N. S. Fan, Liu, S. Luo, J. Yu, J. Huang. Fabrication of polymer-platinumII complex nanomicelle from mPEG-g-alpha, beta-poly[N-amino acidyl-DL-aspartamide] and cis-dichlorodiammine platinumII and its cytotoxicity. Colloids Surf. B 70, 84 (2009).

20. W. Zhu, Y. Li, L. Liu, W. Zhang, Y. Chen, F. Xi. Biamphiphilic triblock copolymer micelles as a multifunctional platform for anticancer drug delivery. J. Biomed. Mater. Res. A 96, 330 (2011).

21. A. Kowalczuk, E. Stoyanova, V. Mitova, P. Shestakova, G. Momekov, D. Momekova, N. Koseva. Star-shaped nanoconjugates of cisplatin with high drug payload. Int. J. Pharm. 404, 220 (2011).

22. G.S. Grest, L.J. Fetters, J.S. Huang. Star polymers: Experiment, theory, and simulation. Adv. Chem. Phys. 94, 67 (1996).

23. M. Ballauff. Spherical polyelectrolyte brushes. Polym. Sci. 32, 1135 (2007)

24. J.M. Ren, T.G. McKenzie, Q. Fu, H.H. Wong, J. Xu et al. Star Polymers. Chem. Rev. 116, 6743 (2016).

25. N.V. Kutsevol, V.A. Chumachenko, M. Rawiso, V.F. Shkodich, O.V. Stoyanov. Star-like polymers dextran-polyacrylamide: The prospects of application for nanotechnology. J. Str. Chem. 56, 1016 (2015).

26. O.A. Yeshchenko, N.V. Kutsevol, A.P. Naumenko. Lightinduced heating of gold nanoparticles in colloidal solution: Dependence on detuning from surface plasmon resonance. Plasmonics 11, 345 (2016).

27. N. Kutsevol, M. Bezuglyi, M. Rawiso, T. Bezugla. Star-like destran-graft-polyacrylamide-co-polyacrylic acid copolymers. Macromol. Symp. 335, 12 (2014).

28. N. Kutsevol, R. Soushko, A. Shyichuk, N. Melnyk. Flocculation behaviour of polymer brushes of various nanostructure. Mol. Liq. Mol. Cryst. 483, 71 (2008).

29. G. Telegeev, N. Kutsevol, V. Chumachenko, A. Naumenko, P. Telegeeva, S. Filipchenko, Yu. Harahuts. Dextranpolyacrylamide as matrices for creation of anticancer nanocomposite. Intern. J. Pol. Sci., 2017.

30. J. Liu, Y. Zhao, Q. Guo, Z. Wang, H. Wang, Y. Yang, et al. TAT-modified nanosilver for combating multidrugresistant cancer Biomaterials 33, 6155 (2012).

31. R. Foldbjerg, D.A. Dang, H. Autrup. Cytotoxicity and genotoxicity of silver nanoparticles in the human lung cancer cell line, A549. Arch. Toxicol. 85, $743 e 50$ (2011).

32. M.I. Sriram, S.B.M. Kanth, K. Kalishwaralal, S. Gurunathan. Antitumor activity of silver nanoparticles in Dalton's lymphoma ascites tumor model. Int. J. Nanomedicine 5, $753 \mathrm{e} 62$ (2010).

33. P. Sanpui, A. Chattopadhyay, S.S. Ghosh. Induction of apoptosis in cancer cells at low silver nanoparticle concentrations using chitosan nanocarrier. ACS Appl. Mater. Interfaces 3, $218 \mathrm{e} 28$ (2011).

34. V. Chumachenko, N. Kutsevol, Yu. Harahuts, M. Rawiso, A. Marinin, L. Bulavin. Star-like Dextran-graft-PNiPAM copolymers. Effect of internal molecular structure on the phase transition. J. Mol. Liq. 235, 77 (2017).

35. B. Koleva, T. Kolev, M. Spiteller. Spectroscopic analysis and structural elucidation of small peptides - experimental and theoretical tools. Book chapter, edited by J.C. Taylor, Advances in Chemistry Research 3, 675 (2010).

36. Y. Ramos, C. Fernández, L. Fernandez, M. Bataller, E. Veliz, R. Small. Optimization of a HPLC procedure for simultaneous determination of cisplatin and the complex cis, cis, trans-diamminedichlorodihydroxoplatinumIV in aqueous solutions. Quimica Nova 34, 1450 (2011).

37. http://www.sigmaaldrich.com/technical-documents/articles/materials-science/nanomaterials/silver-nanoparticles.html

38. K. Shimizu, J. Shibata, H. Yoshida, A. Satsuma, T. Hattori. Silver-alumina catalysts for selective reduction of NO by higher hydrocarbons: Structure of active sites and reaction mechanism. Appl. Catalysis B Environ. 30, 151 (2001).

39. T. Linnert, P. Mulvaney, A. Henglein, H. Weller. Longlived nonmetallic silver clusters in aqueous solution: Preparation and photolysis. J. Am. Chem. Soc. 112, 4657 (1990).

40. C. Noguez. Surface plasmons on metal nanoparticles: The influence of shape and physical environment. J. Phys. Chem. C 111, 3806 (2007).

41. V. Amendola, O.M. Bakr, F. Stellacci. A study of the surface plasmon resonance of silver nanoparticles by the discrete dipole approximation method: Effect of shape, size, structure, and assembly. Plasmonics 5, 85 (2010).

Received 01.02.18

Н.В. Куцевол, А.П. Науменко, В.А. Чумаченко,

О.А. Єщенко, Ю.І. Гарагуи, В.О. Павленко

АГРЕГАТОУТВОРЕННЯ У ПОТРІЙНИХ

НАНОСИСТЕМАХ ПОЛІМЕР/СРІБНІ

НАНОЧАСТИНКИ/ЦИСПЛАТИН

$\mathrm{P}$ е $з$ ю м е

Гібридні наносистеми, що складаються із зіркоподібного сополімеру Декстран-графт-поліакриламід у аніонній формі (D-g-PAA(PE)), наночастинок (АgНЧ) срібла та цисплатину (cis-Pt), синтезовані у воді та охарактеризовані з використанням методів трансмісійної електронної мікроскопії (ТЕM), динамічного розсіяння світла, інфрачервоної Фур'є спектроскопії та спектрофотометрії. Показано, що cis-Pt утворює комплекс з карбоксилатними групами полімеру. Для потрійної системи полімер/AgНЧ/cis-Pt виявлено зміну гідрофільно-гідрофобного балансу молекули полімеру (через комплексоутворення з cis-Pt), агрегацію макромолекул, а також деяких агломераційних AgНЧ. Обговорюється зменшення протипухлинної ефективності гібридної потрійної наносистеми полімер/срібні наночастинки/цисплатин у порівнянні з системою полімер/цисплатин 